DOE/FETC-99/1100

\title{
Waste Management Project Contingency Analysis
}

Edward L. Parsons, Jr.

Center for Acquisition and Business Excellence

August 1999

U.S. Department of Energy

Federal Energy Technology Center

Pittsburgh, Pennsylvania

Morgantown, West Virginia

FETC's Customer Service Line: (800)553-7681

FETC's Homepage: http://www.fetc.doe.gov/ 


\section{Disclaimer}

This report was prepared as an account of work sponsored by an agency of the United States Government. Neither the United States Government nor any agency thereof, nor any of their employees, makes any warranty, express or implied, or assumes any legal liability or responsibility for the accuracy, completeness, or usefulness of any information, apparatus, product, or process disclosed, or represents that its use would not infringe privately owned rights. Reference therein to any specific commercial product, process, or service by trade name, trademark, manufacturer, or otherwise does not necessarily constitute or imply its endorsement, recommendation, or favoring by the United States Government or any agency thereof. The views and opinions of authors expressed therein do not necessarily state or reflect those of the United States Government or any agency thereof.

Available to DOE and DOE contractors from the Office of Scientific and Technical Information, P.O. Box 62, 175 Oak Ridge Turnpike, Oak Ridge, TN 37831; prices are available by phone: (423)576-8401; fax: (423)576-5725; or e-mail: reports@ adonis.osti.gov.

Available to the public from the National Technical Information Service, U.S. Department of Commerce, 5285 Port Royal Road, Springfield, VA 22161; phone orders accepted at (703) 487-4650. 


\begin{abstract}
The purpose of this report is to provide the office of Waste Management (WM) with reccommended contingency calculation procedures for typical WM projects. Typical projects were defined as conventional construction-type activities that use innovative elements when necessary to meet the project objectives. Projects involve treatment, storage, and disposal of low level, mixed low level, hazardous, transuranic, and high level waste.

Cost contigencies are an essential part of Total Cost Management. A contingency is an amount added to a cost estimate to compensate for unexpected expenses resulting from incomplete design, unforseen and unpredictable conditions, or uncertainties in the project scope (DOE 1994, AACE 1998). Contingency allowances are expressed as percentages of estimated cost and improve cost estimates by accounting for uncertainties. The contingency allowance is large at the beginning of a project because there are more uncertainties, but as a project develops, the allowance shrinks to adjust for costs already incurred. Ideally, the total estimated cost remains the same throughout a project. Project contingency reflects the degree of uncertainty caused by lack of project definition, and process contingency reflects the degree of uncertainty caused by use of new technology. Different cost estimation methods were reviewed and compared with respect to terminology, accuracy, and Cost Guide standards.
\end{abstract}

The Association for the Advancement of Cost Engineering (AACE) methods for cost estimation were selected to represent best industry practice. AACE methodology for contingency analysis can be readily applied to WM Projets, accounts for uncertainties associated with different stages of a project, and considers both project and process contingencies and the stage of technical readiness. As reccommended, AACE contingency allowances taper off linearly as a project nears completion. 


\section{Contents}

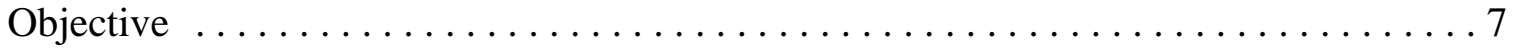

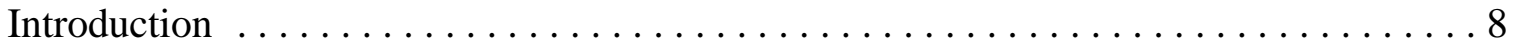

Total Cost Management ............................. 8

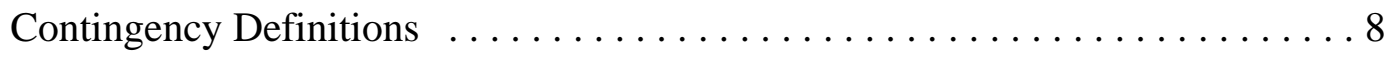

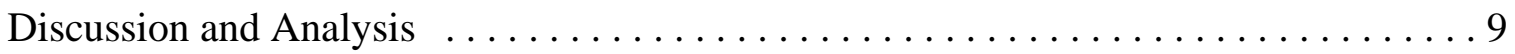

Types of Cost Estimates ................................ 9

Waste Management Project Analysis ........................... 9

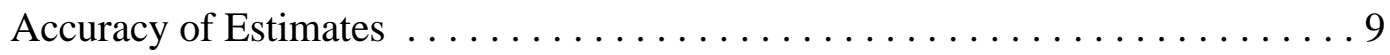

Application of Contingency Allowance to Total Estimated Cost .......... 13

Contingency Allowance Model for WM Projects . . . . . . . . . . . . . . . . . . 14

Waste Management Project Analysis ..................... 14

Types of Contingency for WM Projects . .................. 14

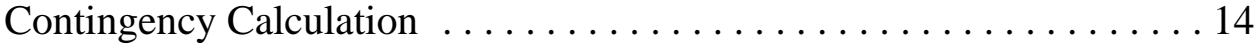

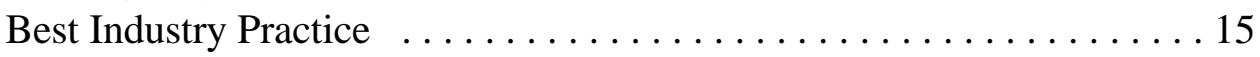

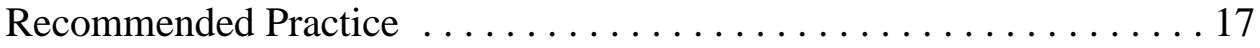

Current Working Estimate ........................ 18

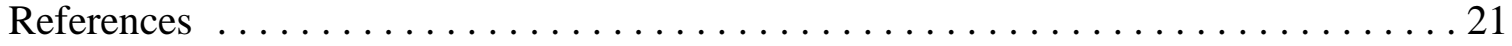

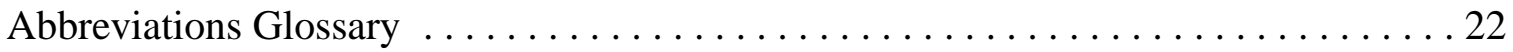




\section{List of Figures}

Figure

Page

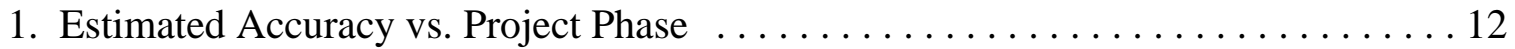

2. Engineering Completion vs. Project Phases $\ldots \ldots \ldots \ldots \ldots \ldots \ldots \ldots \ldots \ldots \ldots \ldots$

3. Ideal Cost Profile - Construction Projects $\ldots \ldots \ldots \ldots \ldots \ldots \ldots \ldots \ldots \ldots \ldots \ldots \ldots$ 


\section{List of Tables}

Table

Page

1. Cost Estimate Classes and Characteristics $\ldots \ldots \ldots \ldots \ldots \ldots \ldots \ldots \ldots$

2. Construction Estimate Classification for Various Technical Standards (AccuracRange

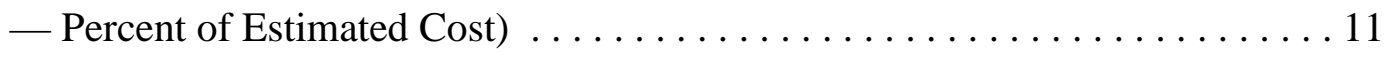

3. Project Contingency Allowance per WBS Item (Expressed as Percent of Estimated

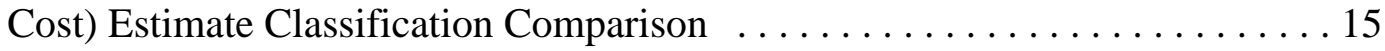

4. Process Contingency per WBS Item: Comparison of Estimate Classes for Various

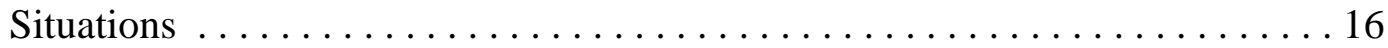

5. Process Contingency Allowance per WBS Item

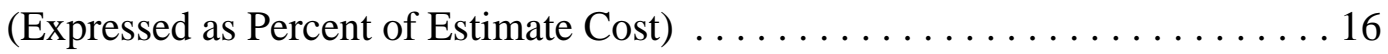

6. Recommended Project Contingency Allowances (Expressed as Percent of Estimated

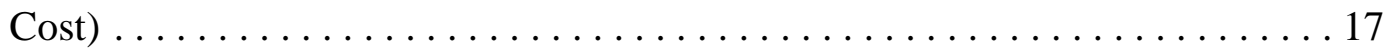

7. Recommended Contingency Allowances (Expressed as Percent of Estimated Cost):

New Design That Requires SOTA Technology . . . . . . . . . . . . . . . . . . 19

8. Recommended Contingency Allowances (Expressed as Percent of Estimated Cost):

New Design with Conceptual Design Report . . . . . . . . . . . . . . . . 19

9. Recommended Contingency Allowances (Expressed as Percent of Estimated Cost):

New Design with Preliminary Design Report . . . . . . . . . . . . . . . . . . 19

10. Recommended Contingency Allowances (Expressed as Percent of Estimated Cost):

Modifications Required to Existing Hardware . . . . . . . . . . . . 20

11. Recommended Contingency Allowances (Expressed as Percent of Estimated Cost):

Existing Hardware Used with No Modifications . . . . . . . . . . . . . 20 


\section{Objective}

The objective is to provide the Office of Waste Management Construction Projects Team with recommended contingency values for typical waste management projects in treatment, storage, and disposal of low level, mixed low level, hazardous, transuranic, and high level waste. This will assist the Projects Team and Waste Management program managers in the review and analysis of waste management project cost estimates. 


\section{Introduction}

\section{Total Cost Management}

Cost contingencies are an essential part of project cost estimating - the keystone of cost engineering and Total Cost Management (TCM). TCM comprises cost analysis, cost control, and cost management at all stages of a project (AACE 1996). From long range planning, through conceptual design, detailed design, and construction, TCM is an essential part of modern project management.

\section{Contingency Definitions}

$\boldsymbol{F A R}$ 31.205-7 defines contingency as a possible future event or condition arising from presently known or unknown causes, the outcome of which is indeterminable at this time. Cost contingencies are used solely for cost estimating. They are not a reimbursable cost under government acquisition rules. FAR 31.205-7 states that costs for contingencies are generally unallowable for historical costing purposes because such costing deals with costs incurred and recorded on the contractor's books.

DOE definines cost contingency as follows:

Cost contingency covers the costs that may result from incomplete design, unforeseen and unpredictable conditions, or uncertainties within the defined project scope. The amount of the contingency will depend on the status of the design, procurement, and construction; and the complexities and uncertainties of the component parts of the project. Contingency is not to be used to avoid making an accurate assessment of the expected cost.

Contingency does not cover major changes in scope or schedule, Acts-of-God, or other Force Majeure situations (DOE 1994).

AACE defines cost contingency as follows:

Contingency is an amount added to an estimate to allow for additional costs that experience shows will likely be required. This may be derived either through statistical analysis of past project costs, or by applying experience gained on similar projects. Contingency usually does not include changes in scope or schedule or unforeseeable major events such as strikes or earthquakes (AACE 1998). 


\section{Discussion and Analysis}

\section{Types of Cost Estimates}

The Association for the Advancement of Cost Engineering (AACE) defines a cost estimate as a compilation of all costs of the elements of a project or effort included within an agreed upon scope (AACE 1998).

Throughout a project, various cost estimates are prepared (each using different methods and data) depending on the degree of project definition that exists at the time of the estimate. AACE identifies three major project stages as exploration, evaluation, and execution.

Estimate terminology, basis, and application as described by Environmental Management (EM) and AACE terminology, are summarized in Table 1. In EM terminology, the exploratory stage (conception) consists of Planning and Conceptual phases. The evaluation stage (basic engineering) consists of Title I design, and the execution stage (detailed engineering and construction) consists of the Title II Design and Construction phases (AACE 1998, DOE 1994).

\section{Waste Management Project Analysis}

Typical WM projects consist largely of conventional construction-type activities and also may use innovative elements where necessary to meet the project objectives. Using innovative elements introduces an additional risk because of uncertainty in the technical performance of a technology (Cost Guide 1995).

\section{Accuracy of Estimates}

As the project stage changes from exploration to evaluation and execution, details become better defined and associated cost estimates become more accurate. Table 2 compares EM and industry estimate classifications, standards of accuracy, and degree of project definition. Stated accuracies have been determined from analysis of past projects (Cost Guide 1995). Estimated accuracy versus project phase was plotted. Electric Power Research Institute (EPRI) and AACE are more conservative than EM with respect to accuracy of estimates at each project phase (Figure 1). The degree of technical definition in terms of percent engineering complete versus project phase was plotted. EM has a higher percent engineering complete at all project phases than AACE (Figure 2). 
Table 1. Cost Estimate Classes and Characteristics

\begin{tabular}{|c|c|c|c|c|}
\hline $\mathbf{A A C E}$ & EM & $\begin{array}{l}\text { Other } \\
\text { Industry } \\
\text { Names }\end{array}$ & Usual Basis & Application \\
\hline $\begin{array}{l}\text { Order of } \\
\text { Magnitude }\end{array}$ & $\begin{array}{l}\text { Planning/ } \\
\text { Feasibility }\end{array}$ & Ratio & $\begin{array}{l}\text { Previous Similar Cost } \\
\text { Information }\end{array}$ & Scoping Studies \\
\hline Study & $\begin{array}{l}\text { Budget/ } \\
\text { Conceptual }\end{array}$ & Factored & $\begin{array}{l}\text { Knowledge of } \\
\text { Flowsheet and Major } \\
\text { Equipment }\end{array}$ & $\begin{array}{l}\text { Assure Project } \\
\text { Feasibility }\end{array}$ \\
\hline Preliminary & Title I & $\begin{array}{l}\text { Initial Budget } \\
\text { Scope }\end{array}$ & $\begin{array}{l}\text { Sufficient Data for } \\
\text { Budget Preparations }\end{array}$ & Verify Costs \\
\hline Definitive & Title II & Project Control & Detailed Data & $\begin{array}{l}\text { Prepare Bid Packages } \\
\text { Construction Budget }\end{array}$ \\
\hline Detailed & Construction & Firm & $\begin{array}{l}\text { Complete Drawings, } \\
\text { Specifications, and } \\
\text { Awarded Contracts }\end{array}$ & $\begin{array}{l}\text { Bid Check } \\
\text { Financial Control }\end{array}$ \\
\hline
\end{tabular}


Table 2. Construction Estimate Classification for Various Technical Standards (Accuracy Range - Percent of Estimated Cost)

\begin{tabular}{|c|c|c|c|c|c|c|}
\hline \multirow[t]{2}{*}{ Source } & \multicolumn{2}{|c|}{ Exploration } & \multicolumn{2}{|c|}{ Execution } & \multicolumn{2}{|c|}{ Execution } \\
\hline & Conception & Exploration & $\begin{array}{l}\text { Concept } \\
\text { Definition }\end{array}$ & $\begin{array}{r}\text { Basic } \\
\text { Engineering } \\
\end{array}$ & $\begin{array}{l}\text { Detailed } \\
\text { Engineering } \\
\end{array}$ & Construction \\
\hline Cost Guide $^{1}$ & $\begin{array}{l}\text { Planning/ } \\
\text { Feasibility } \\
(+/-40 \%)\end{array}$ & $\begin{array}{r}\text { Conceptual } \\
\text { Design/Budget } \\
(+/-30 \%)\end{array}$ & \multicolumn{2}{|c|}{$\begin{array}{c}\text { Title I } \\
(+/-20 \%)\end{array}$} & $\begin{array}{l}\text { Title II } \\
(-5 \text { to }+15 \%)\end{array}$ & $\begin{array}{l}\text { Construction } \\
(-5 \text { to }+10 \%)\end{array}$ \\
\hline $\mathbf{A A C E}^{2}$ & \multicolumn{2}{|c|}{$\begin{array}{c}\text { Class V } \\
(-30 \text { to }+50 \%)\end{array}$} & $\begin{array}{l}\text { Class IV } \\
(-15 \text { to }+30 \%)\end{array}$ & $\begin{array}{l}\text { Class III } \\
\begin{array}{r}(-10 \text { to } \\
+20 \%)\end{array}\end{array}$ & $\begin{array}{l}\text { Class II } \\
(-5 \text { to } 15 \%)\end{array}$ & $\begin{array}{r}\text { Class I } \\
(+/-5 \%)\end{array}$ \\
\hline UK ACE & \multicolumn{2}{|c|}{$\begin{array}{l}\text { Order of Magnitude } \\
\qquad(+/-30 \text { to } 50 \%)\end{array}$} & $\begin{array}{l}\text { Class III } \\
\text { Study }(+/-20 \%)\end{array}$ & $\begin{array}{c}\text { Class II } \\
\text { Budget } \\
(+/-10 \%)\end{array}$ & \multicolumn{2}{|c|}{$\begin{array}{c}\text { Definitive Class I } \\
\qquad(+/-5 \%)\end{array}$} \\
\hline EPRI $^{3}$ & \multicolumn{2}{|c|}{$\begin{array}{l}\text { Class I Simplified } \\
\quad(30 \text { to } 50 \%)\end{array}$} & $\begin{array}{l}\text { Class II } \\
\text { Preliminary } \\
\text { (15 to } 30 \%)\end{array}$ & $\begin{array}{r}\text { Class III } \\
\text { Detailed } \\
(10 \text { to } 20 \%)\end{array}$ & \multicolumn{2}{|c|}{$\begin{array}{l}\text { Class IV Finalized } \\
\qquad(5 \text { to } 10 \%)\end{array}$} \\
\hline ANSI & Ord & $\begin{array}{l}\text { gnitude } \\
0 \%)\end{array}$ & \multicolumn{2}{|c|}{$\begin{array}{c}\text { Budget } \\
(-15 \text { to }+30 \%)\end{array}$} & \multicolumn{2}{|c|}{$\begin{array}{l}\text { Definitive } \\
(+/-5 \%)\end{array}$} \\
\hline
\end{tabular}

${ }^{1}$ Cost Guide, 1994. Volume 6, Table 4-1.

${ }^{2}$ Association for the Advancement of Cost Engineering, 1997. International Recommended Practices and Standards.

${ }^{3}$ Electric Power Resarch Institute, 1993. Technical Assessment Guide, TR-102276-V1R7, Volume 1: Revision 7, Table 5-2. 
Figure 1. Estimate Accuracy vs. Project Phase

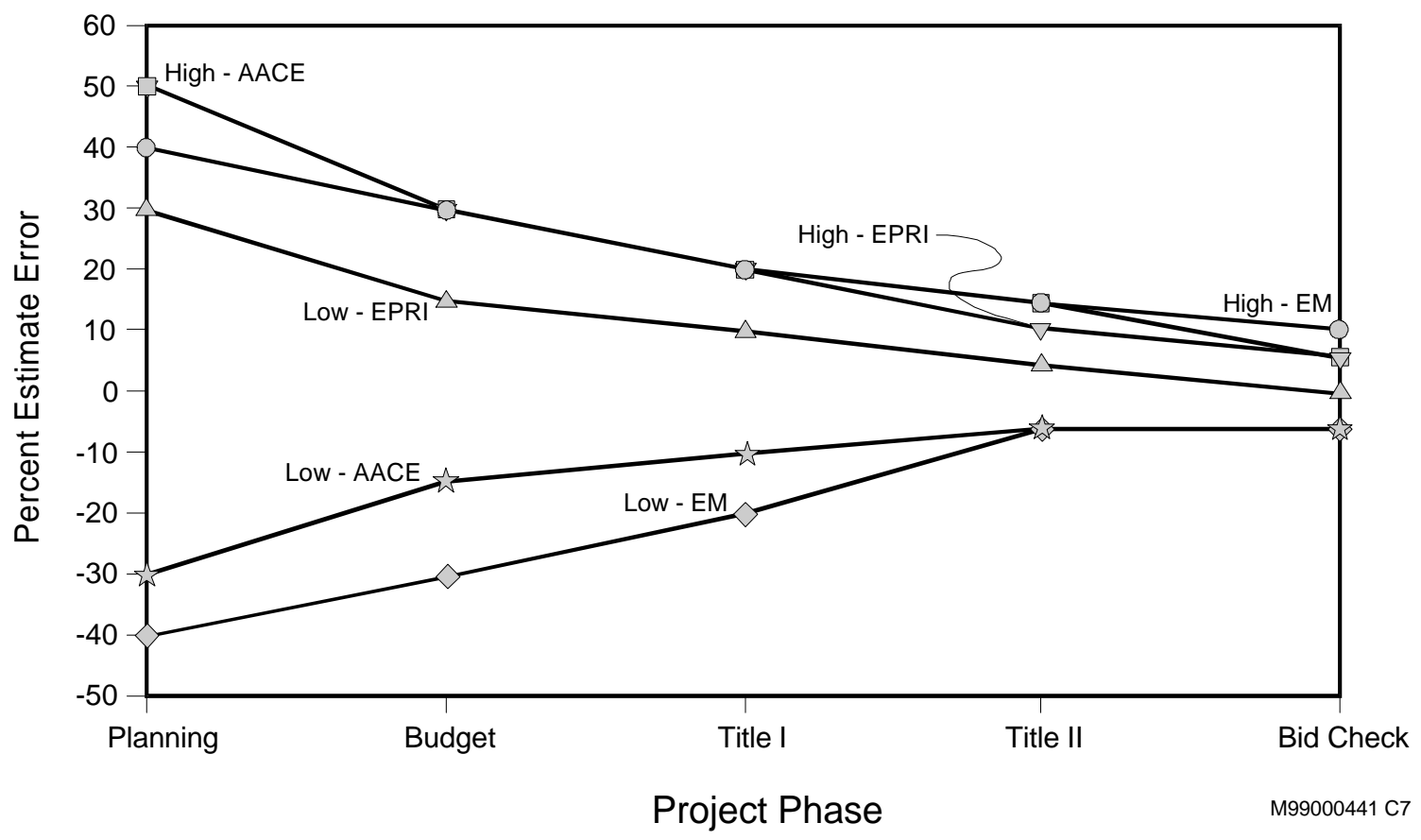

Figure 2. Engineering Completion vs. Project Phase

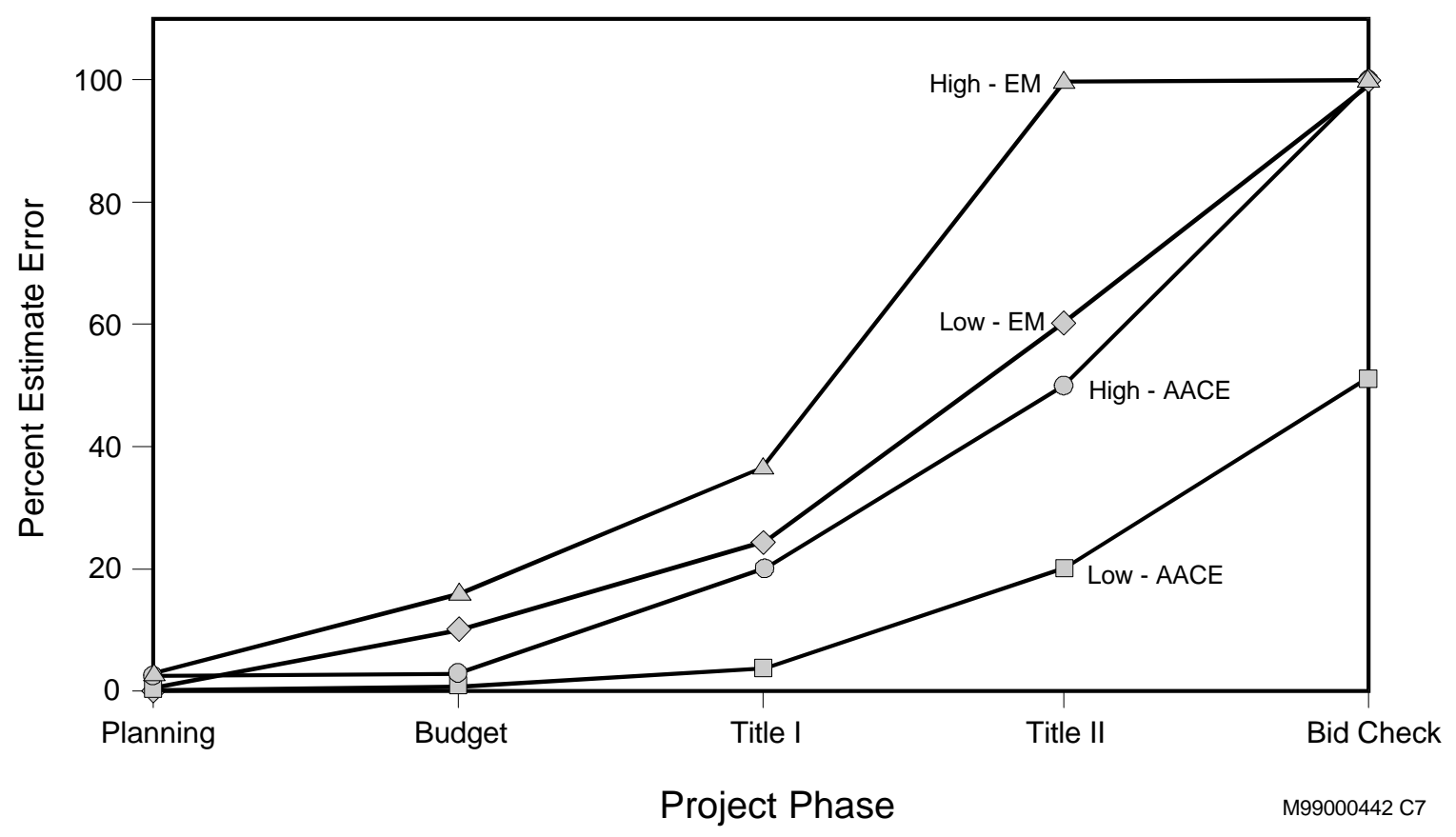




\section{Application of Contingency Allowance to Total Estimated Cost}

The purpose of contingency allowances is to improve the accuracy of cost estimates by compensating for inherent inaccuracies. This compensation is provided in the form of a contingency allowance.

$$
\text { TEC }=\text { Estimated Cost }+ \text { Contingency Allowance, }
$$

where the contingency allowance is large enough to compensate for the maximum range of inaccuracy associated with the estimate.

Early in the project, uncertainties are large and so are inaccuracies. The TEC is calculated by adding a large contingency allowance to a small estimated cost. As the project becomes better defined, more items are included, the estimated cost grows, and the contingency becomes lower, reflecting the reduced degree of uncertainty at that phase of the project. Ideally, the TEC will remain constant throughout a project. As the definition of the project develops, the cost estimate increases and the contingency allowance decreases (Figure 3).

\section{Figure 3. Ideal Cost Profile - Construction Projects}

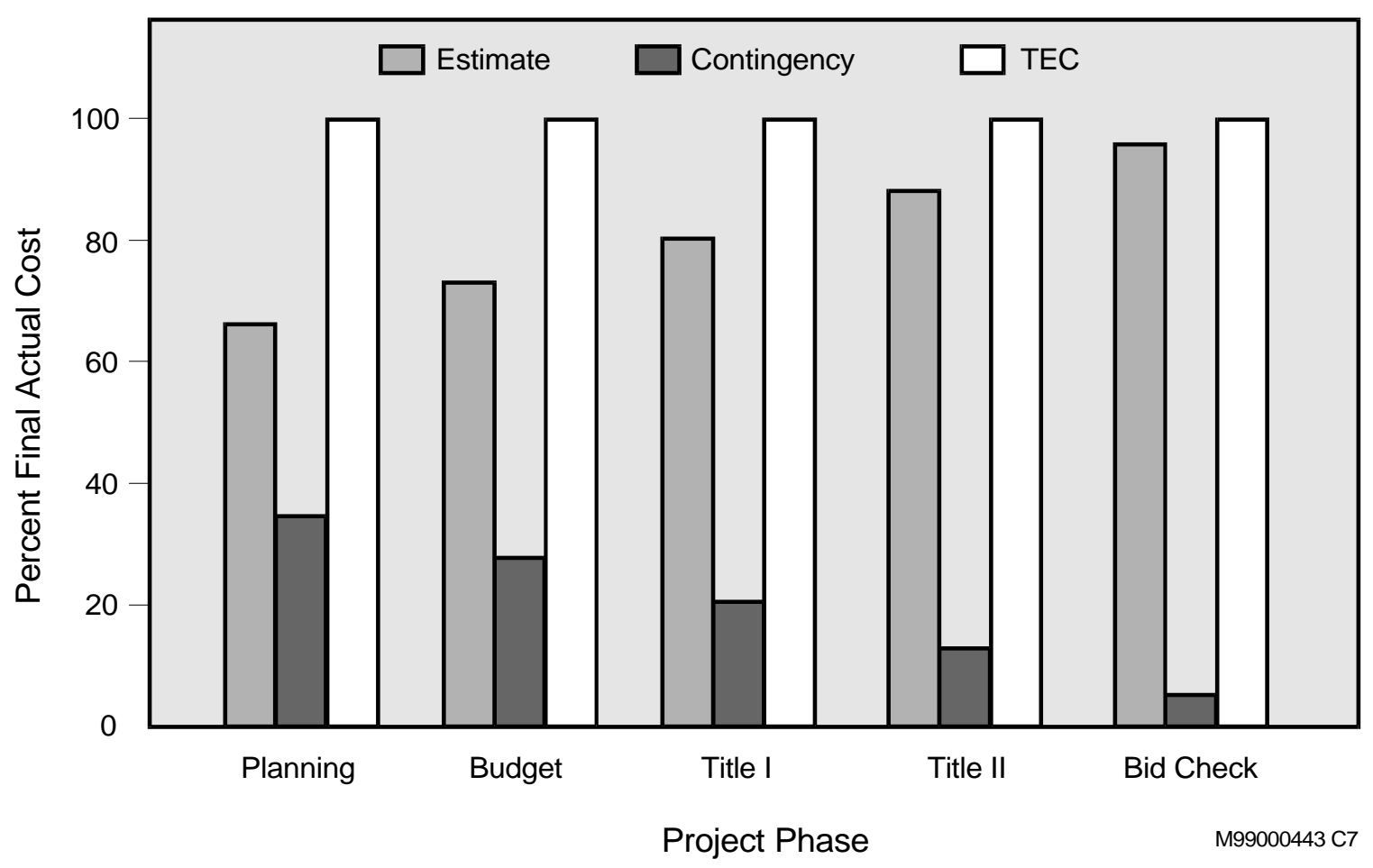




\section{Contingency Allowance Model for WM Projects}

\section{Waste Management Project Analysis}

The Project Performance Study conducted by Independent Project Analysis, Inc.

concluded that WM employs conventional technology and innovates only when there is no available technology that will meet project objectives. Waste Management projects may then be treated as conventional construction projects, with corrections for those innovative elements with higher technical risk involved (Independent Project Analysis, Inc. 1995).

\section{Types of Contingency for WM Projects}

Two types of contingencies are used to compensate for the different types of uncertainties typically encountered in engineering projects - project contingency and process contingency.

Project Contingency is based on the degree of project definition available at the time of making the estimate. This type of contingency covers expected omissions and unforeseen costs caused by lack of complete engineering (Table 3). Project contingency compensates for the inherent estimate inaccuracy associated with each stage of a project (Figure 1). The project contingencies recommended for WM projects are for conventional construction projects.

Process Contingency is based on the degree of uncertainty caused by use of new technology. It is an effort to quantify the uncertainty in performance because of limited technical data. For those technical areas with greater risk, the process contingency is designed to compensate for the inherently greater inaccuracy associated with the cost elements (Table 4).

\section{Contingency Calculation}

The recommended contingency allowance is calculated for each WBS element, using a combination of project and process contingency. Recommended values change according to technology status and project phase (Table 5). AACE has recommended process contingency allowances for each technology situation (Table 6). 


\section{Best Industry Practice}

From a global perspective, WM projects are composed predominantly of conventional construction activities. Cost contingency practices and standards for construction projects by the Association for the Advancement of Cost Engineering (AACE), the American National Standards Institute (ANSI), the Association of Cost Engineering (ACE UK), and the Electric Power Research Institute (EPRI) were reviewed and compared to the Cost Guide (DOE 1994). As a pre-eminent and widely published worldwide authority on project and cost management for construction projects, AACE was selected to represent best industry practice. AACE provides comprehensive, up to date, and well-documented sources of cost data that can readily be applied to WM projects.

Table 3. Project Contingency Allowance per WBS Item (Expressed as Percent of Estimated Cost) Estimate Classification Comparison

\begin{tabular}{|c|c|c|c|c|c|c|}
\hline \multirow[t]{2}{*}{ Source } & \multicolumn{2}{|c|}{ Exploration } & \multicolumn{2}{|c|}{ Evaluation } & \multicolumn{2}{|c|}{ Execution } \\
\hline & Conception & Exploration & $\begin{array}{l}\text { Concept } \\
\text { Definition }\end{array}$ & $\begin{array}{l}\text { Basic } \\
\text { Engineering }\end{array}$ & $\begin{array}{l}\text { Detailed } \\
\text { Engineering }\end{array}$ & Construction \\
\hline \multicolumn{7}{|l|}{ Cost Guide } \\
\hline Type Estimate & Planning & Explortation & \multicolumn{2}{|c|}{ Title I } & Title II & $\begin{array}{r}\text { Government } \\
\text { Bid Check }\end{array}$ \\
\hline $\begin{array}{l}\text { Contingency } \\
\text { Allowance }\end{array}$ & $40 \%$ & $30 \%$ & \multicolumn{2}{|c|}{$20 \%$} & $15 \%$ & $10 \%$ \\
\hline Design Complete & 0 to $5 \%$ & 10 to $15 \%$ & \multicolumn{2}{|c|}{25 to $35 \%$} & 60 to $100 \%$ & $100 \%$ \\
\hline \multicolumn{7}{|l|}{ AACE } \\
\hline Type Estimate & \multicolumn{2}{|c|}{ Class V } & Class IV & Class III & Class II & Class I \\
\hline $\begin{array}{l}\text { Contingency } \\
\text { Allowance }\end{array}$ & \multicolumn{2}{|c|}{$50 \%$} & $30 \%$ & $20 \%$ & $15 \%$ & $5 \%$ \\
\hline Design Complete & \multicolumn{2}{|c|}{0 to $20 \%$} & 1 to $5 \%$ & 5 to $20 \%$ & 20 to $50 \%$ & 50 to $100 \%$ \\
\hline
\end{tabular}


Table 4. Process Contingency per WBS Item: Comparison of Estimate Classes for Various Situations

\begin{tabular}{lcccc}
\hline \multicolumn{1}{c}{ State of Development } & AACE & NASA & EPRI & Cost Guide $^{\mathbf{1}}$ \\
\hline $\begin{array}{l}\text { New Design beyond } \\
\text { SOTA }\end{array}$ & $40 \%+$ & $50 \%$ & $40 \%+$ & up to $50 \%$ \\
New Design within SOTA & $\mathrm{n} / \mathrm{a}$ & $35 \%$ & $\mathrm{n} / \mathrm{a}$ & $\mathrm{n} / \mathrm{a}$ \\
$\begin{array}{l}\text { New Design Hardware } \\
\text { through PDR }\end{array}$ & $30-70 \%$ & $25 \%$ & $30-70 \%$ & up to $40 \%$ \\
$\begin{array}{l}\text { New Design Hardware } \\
\text { through CDR }\end{array}$ & $20-35 \%$ & $20 \%$ & $20-35 \%$ & $15-25 \%$ \\
$\begin{array}{l}\text { Modifications Required } \\
\text { to Existing Hardware }\end{array}$ & $5-20 \%$ & $15 \%$ & $5-20 \%$ & $10-20 \%$ \\
$\begin{array}{l}\text { No Modifications } \\
\text { Required }\end{array}$ & $0-10 \%$ & $10 \%$ & $0-10 \%$ & $5-15 \%$ \\
\hline $\begin{array}{l}\text { Cost Guide, 1994. Volume 6, Table 11-1. } \\
\text { nos }\end{array}$ & & & \\
\end{tabular}

Table 5. Process Contingency Allowance per WBS Item (Expressed as Percent of Estimate Cost)

\begin{tabular}{cc}
\hline State of Development & $\begin{array}{c}\text { AACE } \\
\text { Recommendation }\end{array}$ \\
\hline $\begin{array}{c}\text { New Design beyond } \\
\text { SOTA }\end{array}$ & $40 \%+$ \\
New Design Hardware \\
through CDR \\
$\begin{array}{c}\text { New Desighn Hardware } \\
\text { through PDR } \\
\text { Modifications Required } \\
\text { to Existing Hardware } \\
\text { No Modifications } \\
\text { Required }\end{array}$ \\
\hline
\end{tabular}


Table 6. Recommended Project Contingency Allowances (Expressed as Percent of Estimated Cost)

\begin{tabular}{lcc}
\hline Project Stage & $\begin{array}{c}\text { Project } \\
\text { Contingency }\end{array}$ & $\begin{array}{c}\text { Design } \\
\text { Complete }\end{array}$ \\
\hline Planning & $50 \%$ & $0-2 \%$ \\
Conceptual & $40 \%$ & $1-5 \%$ \\
Title I & $30 \%$ & $5-20 \%$ \\
Title II & $15 \%$ & $20-50 \%$ \\
Construction & $5 \%$ & $50-100 \%$ \\
\hline
\end{tabular}

\section{Recommended Practice}

The recommended contingency analysis, based on AACE guidelines, is performed for each Work Breakdown Structure (WBS) element. This method accounts for uncertainties associated with different phases of the project and uses a combination of project and process contingency. The project contingency reflects the degree of uncertainty in the estimated cost because of incomplete technical definition, and process contingency reflects the degree of uncertainty in the estimated cost because of incomplete design data for new technologies.

For each WBS element, total contingency is calculated as delineated in tables 7, 8, 9, and 10. The recommended allowances are expressed as percentages of estimated cost. Total contingency allowances are summarized versus project phase at different stages of technical readiness. Stages range from a new design that requires technology beyond the current state of the art (SOTA) to existing hardware may be used with no modification.

The exact value is decided by the cost estimator. Total Estimated Cost (TEC) for each element is calculated as follows:

$$
\mathrm{TEC}=\text { Estimated Cost }+ \text { Total Contingency Allowance }
$$

Total Contingency Allowance $=$ Project Contingency + Process Contingency The TEC for the total project is determined by summing the TECs for all WBS elements. 


\section{Current Working Estimates}

A practical concern in the management of large construction projects is how to budget appropriately for contingencies in the latter stages of the project. As substantial portions of the job are completed and actual costs are incurred, it is unrealistic to continue budgeting for the full contingency allowance. Total dollar exposure to cost uncertainties in remaining work is continually reduced as the value of work remaining to be done diminishes. To recognize this reality, the following practice is recommended:

For the preparation of current working estimates of cost-to-complete during the construction phase of the project, it is recommended that the contingency reserve budgeted at the outset of construction be tapered off linearly as the work is accomplished.

TEC $=$ Cost Incurred to Date + Estimated Remaining Cost + Scaled Contingency Allowance

Scaled Contingency Allowance $=$ Original Contingency Allowance x $(\%$ Work Remaining/100 $)$

For example, consider a construction project in which a $\$ 100$ million was the estimated cost for a major WBS element with a contingency allowance of $\$ 5$ million, yielding a TEC of $\$ 105$ million. If the construction phase on the element is $50 \%$ complete, the current working TEC to complete the element would now be the sum of costs incurred to date, the estimated cost remaining, plus one half of the original contingency allowance, or $\$ 2.5$ million. 
Table 7. Recommended Contingency Allowances (Expressed as Percent of Estimated Cost): New Design That Requires SOTA technology

\begin{tabular}{lcccc}
\hline Project Phase & Project & Process & Total & $\begin{array}{c}\text { Design } \\
\text { Complete }\end{array}$ \\
\hline Planning & $50 \%$ & $40 \%+$ & $90 \%+$ & $0-2 \%$ \\
Title I & $30 \%$ & $40 \%+$ & $70 \%+$ & $5-20 \%$ \\
Title II & $15 \%$ & $40 \%+$ & $55 \%+$ & $20-50 \%$ \\
Construction & $5 \%$ & $40 \%+$ & $45 \%+$ & $50-100 \%$ \\
\hline
\end{tabular}

Table 8. Recommended Contingency Allowances (Expressed as Percent of Estimated Cost): New Design With Conceptual Design Report

\begin{tabular}{lcccc}
\hline Project Phase & Contingency & Design \\
& Project & Process & Total & Complete \\
\hline Conceptual & $40 \%$ & $30-70 \%$ & $70-110 \%$ & $1-5 \%$ \\
Title I & $30 \%$ & $30-70 \%$ & $60-100 \%$ & $5-20 \%$ \\
Title II & $15 \%$ & $30-70 \%$ & $45-85 \%$ & $20-50 \%$ \\
Construction & $5 \%$ & $30-70 \%$ & $35-75 \%$ & $50-100 \%$ \\
\hline
\end{tabular}


Table 9. Recommended Contingency Allowances (Expressed as Percent of Estimated Cost): New Design With Preliminary Design Report

\begin{tabular}{lcccc}
\hline Project Phase & Project & Process & Total & $\begin{array}{c}\text { Design } \\
\text { Complete }\end{array}$ \\
\hline Conceptual & $40 \%$ & $20-35 \%$ & $60-75 \%$ & $1-5 \%$ \\
Title I & $30 \%$ & $20-35 \%$ & $50-65 \%$ & $5-20 \%$ \\
Title II & $15 \%$ & $20-35 \%$ & $35-50 \%$ & $20-50 \%$ \\
Construction & $5 \%$ & $20-35 \%$ & $25-40 \%$ & $50-100 \%$ \\
\hline
\end{tabular}

Table 10. Recommended Contingency Allowances (Expressed as Percent of Estimated Cost): Modifications Required to Existing Hardware

\begin{tabular}{lcccc}
\hline Project Phase & Project & Process & Total & $\begin{array}{c}\text { Design } \\
\text { Complete }\end{array}$ \\
\hline Conceptual & $40 \%$ & $5-20 \%$ & $45-60 \%$ & $1-5 \%$ \\
Title I & $30 \%$ & $5-20 \%$ & $35-50 \%$ & $5-20 \%$ \\
Title II & $15 \%$ & $5-20 \%$ & $20-35 \%$ & $20-50 \%$ \\
Construction & $5 \%$ & $5-20 \%$ & $10-25 \%$ & $50-100 \%$ \\
\hline
\end{tabular}


Table 11. Recommended Contingency Allowances (Expressed as Percent of Estimated Cost): Existing Hardware Used With No Modifications

\begin{tabular}{lcccc}
\hline Project Phase & Project & Process & Total & $\begin{array}{c}\text { Design } \\
\text { Complete }\end{array}$ \\
\hline Conceptual & $40 \%$ & $0-10 \%$ & $40-50 \%$ & $1-5 \%$ \\
Title I & $30 \%$ & $0-10 \%$ & $30-40 \%$ & $5-20 \%$ \\
Title II & $15 \%$ & $0-10 \%$ & $15-25 \%$ & $20-50 \%$ \\
Construction & $5 \%$ & $0-10 \%$ & $5-15 \%$ & $50-100 \%$ \\
\hline
\end{tabular}




\section{References}

Association for the Advancement of Cost Engineering (AACE), 1998. Construction Cost Estimating.

Association for the Advancement of Cost Engineering (AACE), 1997. International Recommended Practices and Standards.

Association for the Advancement of Cost Engineering (AACE), 1996. PreliminaryCapital and Operating Cost Estimating.

Cost Guide, 1994. Volume 6.

Department of Energy, year. Project Management System, DOE Order 4700.1

Electric Power Research Institute (EPRI), 1993. Technical Assessment Guide, TR-102276-V1R7, Vol. 1:Rev. 7.

Independent Project Analysis Inc., 1996. Project Performance Study Update, Waste Management Addendum, Federal Energy Technology center.

Independent Project Analysis Inc., 1995. Project Performance Study, Waste Management Addendum, Federal Energy Technology Center.

National Aeronautics and Space Administration (NASA), 1999. Parametric Cost

Estimating Manual, Johnson Space Center, http://www.jsc.nasa.gov/ [April 1999]. 


\section{Abbreviations}

AACE Association for the Advancement of Cost Engineering

ANSI American National Standards Institute

CDR Conceptual Design Report

EPRI Electric Power Research Institute

EM Environmental Management

PDR Preliminary Design Report

SOTA State of the Art

TCM Total Cost Management

TEC Total Estimated Cost

WM Waste Management 